\title{
Ratio - First Order Derivative - Zero Crossing UV-Visible Spectrophotometric Method for Analysis of Amoxicillin, Levofloxacin and Lansoprazole Mixture
}

\author{
Mustafa Gülfen*, Yazg1 Canbaz and Abdil Özdemir \\ Department of Chemistry, Faculty of Arts and Sciences, Sakarya University, 54187 Sakarya, Turkey. \\ *Coressponding Author Email: mgulfen@sakarya.edu.tr \\ Received 09 March 2020, Revised 10 June 2020, Accepted 15 June 2020
}

\begin{abstract}
A ratio - first order derivative - zero crossing UV-Visible (UV-Vis) spectrophotometric method has been developed for the simultaneous determination of amoxicillin (Amox), levofloxacin (Levo) and lansoprazole (Lanso). The method was validated for the mixtures of Amox, Levo and Lanso in the standard solutions and pharmaceutical tablets. Amox, Levo and Lanso solutions prepared in $\mathrm{MeOH}: \mathrm{H}_{2} \mathrm{O}(50: 50 \mathrm{v} / \mathrm{v})$ solvent mixture were used in the measurements. The calibration graphs were prepared at the wavelengths of 248.9, 219.4 and $262.8 \mathrm{~nm}$, respectively, which were determined as the zero crossing points of the ratio - first order derivative spectra of them. The calibration curves were optimized linearly between the concentrations of $1.22-15.0$ $\mathrm{mg} / \mathrm{L}$ for Lanso, $0.95-20.0 \mathrm{mg} / \mathrm{L}$ for Levo and $3.42-40 \mathrm{mg} / \mathrm{L}$ for Amox together with the correlation coefficients $\left(R^{2}\right) 0.9996,0.9993$ and 0.9987 , respectively. The limits of detection (LODs) of the improved method were $\leq 1.03 \mathrm{mg} / \mathrm{L}$ concentration, and the limits of quantification (LOQs) were $\leq 3.42 \mathrm{mg} / \mathrm{L}$. The proposed ratio- first order derivative zero-crossing method was validated with good accuracies as the recoveries of $100.0 \%, 102.5 \%$ and $99.2 \%$ and with high precisions as the RSDs \% of 1.37, 2.04 and 2.64 for Amox, Levo and Lanso, respectively. It was shown that the Amox, Levo and Lanso can be determined simultaneously without any separation in pharmaceutical mixture formulations.
\end{abstract}

Keywords: Amoxicillin, Levofloxacin, Lansoprazole, Ratio - first order derivative - zero crossing. UV-vis. absorption spectroscopy

\section{Introduction}

In present work, simultaneous analysis of amoxicillin (Amox), levofloxacin (Levo) and lansoprazole (Lanso) ternary drug mixtures was studied. Amox is one of antibiotics of penicillin group [1, 2]. Its chemical name is $(2 \mathrm{~S}, 5 \mathrm{R}, 6 \mathrm{R})$ [[(2R)-2-amino-2 (4-hydoxyphenyl)acetyl]amino]3,3-dimethyl-7-oxo-4-thia-1-azabiccyclo [3.2.0] heptanes-2-carboxyic acid [3]. The molecular formula of Amox is shown in Fig. 1a. It is used for the infections by penicillin-sensitive grampositive bacteria and some gram-negative bacteria [2]. Levo is a synthetic broad spectrum antibiotic, which is taken orally. It is included in fluoroquinolone antibiotics [4]. Levo is named systematically as (-)-(S)-9-fluoro-2,3-dihydro-3methyl-10-(4-methyl-1-pipe-razinyl)-7oxo-7Hpyrido [1,2,3-de]- 1, 4-benzoxazine-6-carboxylic acid hemihydrate [5]. The formula of Levo is demonstrated in Fig. 1b [6]. It is effective for gram-positive and gram-negative bacteria and inhibits DNA gyrase [4]. It is used in case of respiratory, skin or soft tissues, and urinary system infections [6, 7]. Lanso is one of acid pump inhibitor agents. It acts to acid secretion mechanism in parietal cells. The chemical name of Lanso is (2-[[[3-Methyl-4-(2,2,2-trifluoroethoxy)2- pyridyl]methyl]sulfinyl]-lH-benzimidazole) [8]. Its molecular structure is given in Fig.1c. Lanso 
helps to decrease the acid in stomach and to prevent the stomach affected by ulcer [9]. In the treatment of gastric ulcers, Lanso is used together with some antibiotics such as Amox and clarithromycin [8]. Therefore, the simultaneous determination method of Lanso together with antibiotics is important.

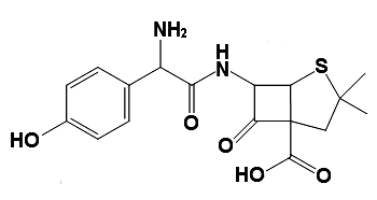

a) Amoxicillin

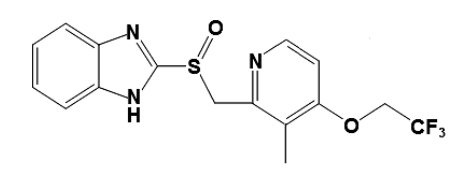

c) Lansoprazole

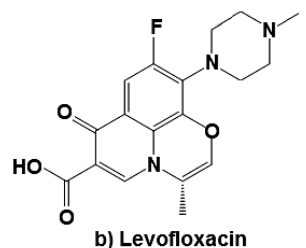

$\mathrm{CF}_{3}$
Figure 1. Chemical structures of a) Amoxicillin, b) Levofloxacin and c) Lansoprazole

UV-Vis absorption spectrophotometry [10-15], spectrofluorimetry [16, 17], HPLC [18-22], thin-layer chromatography (TLC) [23], electrochemical [24-29] and LC-MS/MS [30] methods have been used for the determination of Amox, Levo and Lanso. Among these methods, UV-Vis absorption spectrophotometry is a widespread used analytical method and UV-Vis spectrophotometers are available basic instrument in every analytical laboratory. Different techniques can be used with UV-Vis spectrophotometry. First order derivative, second order derivative and ratio - derivative - zero crossing methods can be applied to binary or ternary mixtures of pharmaceuticals [3-33].

In the present work, a ratio - first order derivative - zero crossing UV-Vis spectrophotometric method was applied well to determine the ternary mixtures of Amox, Levo and Lanso. The method is based on the successive derivative of ratio spectra in two successive steps. Firstly, the absorption spectra of the ternary mixtures were divided by the standard spectrum of one component to obtain the ratio spectrum. Then, the first order derivative of the ratio spectra was taken and the calibration curve is formed at the zero crossing points of the other component. By using a second divisor, all the components of ternary mixtures can be determined similarly. A simultaneous UV-Vis absorption spectrophotometric method for the combination of Amox, Levo and Lanso has not been found in the literature which we can reach, although there are UV-Vis methods for the combinations of them with other drugs. The novelty of study is the developing the UV-vis. absorption spectrophotometric method for the combination of Amox, Levo and Lanso. Hence, a ratio- first order derivative - zero crossing UV-Vis spectrophotometric method has been developed to determine simultaneously the ternary mixtures of Amox, Levo and Lanso drug agents in pharmaceutical tablets. The validated method can be applied without any previous separation. After the optimization of the calibration curves of them, their ternary mixtures were analyzed.

\section{Materials and Methods Materials}

Amox trihydrate, Levo hemihydrate and Lanso were purchased from Neutec Pharmaceuticals (Sakarya, Turkey). They were used for the standard calibration solutions. In the validation measurements, Largopen including $1176.47 \mathrm{mg}$ Amox trihydrate or $1000 \mathrm{mg}$ Amox was used. It was produced by Bilim Pharmaceuticals Company (Tekirdag, Turkey). Levo measurements were done by using Tavanic drug tablets which are produced by Sanofi Aventis Limited Company (Istanbul, Turkey). One Tavanic tablet contains $512.6 \mathrm{mg}$ Levo hemihydrate. It is equivalent to $500 \mathrm{mg}$ Levo. For the validation measurements of Lanso, Lansor pharmaceutical tablets were used. Lansor is produced by Sanovel Company (Istanbul, Turkey). Each Lansor tablet includes $30 \mathrm{mg}$ active Lanso agent. The other chemicals were in analytical grade. In the preparation of the solutions, ultrapure water (18.2 M $\Omega$ ) and high purity methanol solvents were used.

\section{Instrument}

In UV-Vis absorption measurements, a Shimadzu 2600 model UV-Vis Spectrophotometer (Japan) was used. The UV-Vis Spectrophotometer has double beam system with $1.0 \mathrm{~cm}$ path lengths. In the measurements, $1.0 \mathrm{~cm}$-path 
length quartz cells were used. All the spectra were recorded at the wavelengths of $200-400 \mathrm{~nm}$ with the resolution of $0.1 \mathrm{~nm}$.

\section{Zero order spectra $U V$-Vis absorption spectra}

The standard solutions of Amox, Levo and Lanso were prepared separately in $\mathrm{MeOH}: \mathrm{H}_{2} \mathrm{O}$ (50:50 v/v) solvent mixture. The Amox standard solutions were prepared at the concentrations of $15,20,25,30,35$ and $40 \mathrm{mg} / \mathrm{L}$. The Lanso calibration solutions were at the concentrations of $2.5,5.0,7.5,10.0,12.5$ and $15.0 \mathrm{mg} / \mathrm{L}$ and the Levo solutions were at the concentrations of 7.5, $10.0,12.5,15.0,17.5$ and $20.0 \mathrm{mg} / \mathrm{L}$. The serial calibration solutions were named as Amox1, Amox2, ... Amox6; Lanso1, Lanso2, .... Lanso6, and Levo1, Levo2, ... Levo6 as the increasing concentrations of them (Amox1-6: 15, 20, 25, 30, 35 and $40 \mathrm{mg} / \mathrm{L}$; Lanso1-6: 2.5, 5.0, 7.5, 10.0, 12.5 and $15.0 \mathrm{mg} / \mathrm{L}$; Levo1-6 7.5, 10.0, 12.5, 15.0, 17.5 and $20.0 \mathrm{mg} / \mathrm{L}$ ). The UV-Vis spectra of these prepared standard solutions were measured separately in the range of 200-400 nm wavelengths.

\section{Ratio - first order derivative - zero crossing UV- Vis absorption spectra}

To obtain the calibration curves for each of the ratio spectra were obtained by dividing the zero order spectra of two components to the zero order spectrum of third component. The spectra of Amox1-6 (15 - $40 \mathrm{mg} / \mathrm{L})$ and Lanso1-6 (2.5 $15.0 \mathrm{mg} / \mathrm{L}$ ) standard solutions were divided by Levo6 $(20.0 \mathrm{mg} / \mathrm{L})$ and they were assigned as 1) Amox1-6/Levo6 and Lanso1-6/Levo6. Next, the spectra of Lanso1-6 (2.5 - $15.0 \mathrm{mg} / \mathrm{L})$ and Levo1$6(7.5-20.0 \mathrm{mg} / \mathrm{L})$ standard solutions were divided by Amox6 $(40 \mathrm{mg} / \mathrm{L})$ as second divisor and these group was assigned as 2) Lanso16/Amox6 and Levo1-6/Amox6. Then, the first order derivatives of the ratio spectra were taken by selecting $\Delta \lambda: 10.0 \mathrm{~nm}$ and scaling factor: 1 . The zero crossing points of one component in the obtained spectra were determined.

\section{Calibration curves}

After the ratio - first order derivative spectra was obtained, the zero crossing points of one component on the ratio - first order derivative spectra were selected for the calibration curves of Amox, Levo and Lanso at the wavelengths of 248.9, 262.8 and $219.4 \mathrm{~nm}$, respectively. The calibration curves were obtained for Amox, Levo and Lanso at previously determined concentrations which are $15,20,25,30,35$ and $40 \mathrm{mg} / \mathrm{L}$ for Amox, 2.5, 5.0, 7.5, 10.0, 12.5 and $15.0 \mathrm{mg} / \mathrm{L}$ for Lanso $7.5,10.0,12.5,15.0,17.5$ and $20.0 \mathrm{mg} / \mathrm{L}$. for Levo.

\section{Validation}

For the validation of the proposed ratio first order derivative - zero crossing UV-Vis spectrophotometric method, the accuracy as recovery\% and the precision as percent relative standard deviation (RSD\%) experiments were conducted in the ternary mixtures. Eighteen synthetic ternary mixture solutions of Amox, Levo and Lanso were prepared. The concentrations of them are in the range of the concentrations of the calibration standard solutions. The UV-Vis absorption spectra were recorded by changing the concentrations of Amox, Levo and Lanso in their ternary mixtures. From the obtained spectra, the percent recoveries and percent relative standard deviations (RSD\%) were calculated as the accuracy and precision of the proposed method.

\section{Analysis of pharmaceutical tablets}

The pharmaceutical tablets were weighted and powdered with mortar. Largopen pharmaceutical tablets were dissolved in $500 \mathrm{~mL}$ $\mathrm{MeOH}: \mathrm{H}_{2} \mathrm{O}$ (50:50v/v). One Largopen tablet contains 1000 mg Amox. Lansor tablets for Lanso agent were dissolved in $250 \mathrm{~mL} \mathrm{MeOH}$. Each Lansor tablet has $30 \mathrm{mg}$ Lanso drug agent. Tavanic tablets for Levo were dissolved in $250 \mathrm{~mL}$ $\mathrm{MeOH}: \mathrm{H}_{2} \mathrm{O}$ (50:50v/v). One Tavanic tablet includes $500 \mathrm{mg}$ Levo. Through the dissolution processes of pharmaceutical tablets, the undissolved solid particles were filtered with 0.2 $\mu \mathrm{m}$ membrane filter in a vacuum filter system. Then, six ternary mixture solutions including 25 $\mathrm{mg} / \mathrm{L}$ Amox, $7.5 \mathrm{mg} / \mathrm{L}$ Lanso and $12.5 \mathrm{mg} / \mathrm{L}$ Lanso were prepared. Their UV-Vis spectra were measured and their concentrations were calculated using the calibration curves of them. 
Results and Discussion

\section{Zero order UV-Vis absorption spectra}

The zero order spectra of Amox, Levo and Lanso drug reagents in $\mathrm{H}_{2} \mathrm{O}: \mathrm{MeOH}(50: 50 \mathrm{v} / \mathrm{v})$ solvent mixture were measured separately. The obtained spectra of Amox, Levo and Lanso at the different standard calibration concentrations are given in Fig. 2. It can be seen from the spectra that the maximum absorption bands of Amox were observed at the wavelengths of 205, 231 and 274 $\mathrm{nm}$. The maximum absorption bands of Levo were seen at the wavelengths of 228, 258, 292 and 330 $\mathrm{nm}$. For the Lanso, the maximum bands were at the wavelengths of 205 and $286 \mathrm{~nm}$. The absorption bands of all of Amox, Levo and Lanso overlapped at the wavelengths below $292 \mathrm{~nm}$. Levo and Lanso absorption bands overlapped at wavelengths below $314 \mathrm{~nm}$ Levo can be determined independently from the others at the wavelengths of about $315-345 \mathrm{~nm}$, if it is calibrated. Levo and Lanso can be determined in their binary mixtures between 290 and $370 \mathrm{~nm}$ wavelengths. However, in any case, the absorption bands of Amox overlap with the other two components. Therefore, the determination of Amox requires the applications of chemometric or graphical methods to resolve the spectra and to calculate the individual concentrations of the components. One of the ternary mixture methods is ratio-derivative $-\mathrm{z}$ ero crossing $\mathrm{UV}$-Vis spectrophotometric method. It is possible to determine simultaneously the ternary mixtures of Amox, Levo and Lanso at about $210-300 \mathrm{~nm}$ wavelength in which all the absorption bands of them overlapped on each other. Hence, in this study, a ratio- derivative zero-crossing UV-Vis spectrophotometric method was developed and validated for the ternary mixtures of Amox, Levo and Lanso.

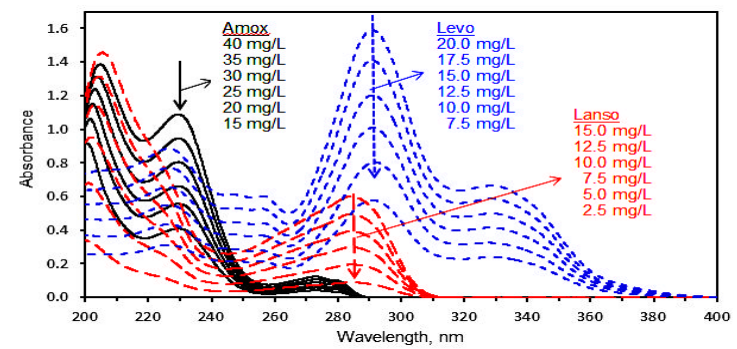

Figure 2. Zero order UV-Vis absorption spectra of Amox, Levo and Lanso at different concentrations (Solvent: $\mathrm{H}_{2} \mathrm{O}: \mathrm{MeOH}$, 50:50v/v)
Ratio - first order derivative - zero crossing $U V$ Vis absorption spectra

Salinas et al. [34] applied the ratioderivative spectrophotometry to binary mixtures. Then, Nevado et al. [35] developed the method and applied to ternary mixtures by using first order derivative of the ratio spectra of ternary mixtures. They calculated the calibration curves at the zero crossing wavelengths of the first order derivative of the ratio spectra [35]. In ratio - first order derivative - zero crossing method, after the ratio spectra of two analytes to third one were obtained, the two ratio spectra were derived. Any wavelength of the maximums or minimums of one analyte at the zero crossing wavelength of other analyte were used for the calibration calculations. To obtain many maximums or minimums are possible and this is advantage of the method. The aimed analyte can be determined selectively with the ratio - first order derivative - zero crossing method in case of presence of other matrix compounds [36].

In this study, the spectra of the first and second analytes were divided by the spectrum of third analyte standard solution. It is possible to obtain three new ratio spectra as 1) Amox/Levo and Lanso/Levo, 2) Amox/Lanso and Levo/Lanso and 3) Lanso/Amox and Levo/Amox. By dividing these spectra, the ternary variant spectra were reduced to binary variant spectra. Then, these ratio spectra were derived and finally the calibration curves as one variant were formed at zero crossing points of second analyte. With the ratio - first order derivative - zero crossing procedure, many calibration points can be obtained for three analytes. In this study, two new spectra group were obtained as 1) Amox1-6/Levo6 and Lanso16/Levo6, and 2) Lanso1-6/Amox6 and Levo16/Amox6 by using the ratio - first order derivative. Double divisors, Levo6 and Amox 6 standard solutions, were used in total. The obtained ratio - first order derivative spectra are given in Fig. 3 and Fig. 4. After ratio - first derivative spectra were drawn, the zero crossing points were obtained for third component. There are more than one zero crossing points in the obtained spectra to select a calibration point for suitable component. The selected zero crossing points were determined according to more 
absorbance distributions of the varying component. So, the calibration curves of Amox, Levo and Lanso were formed by using ratio - first order derivative - zero crossing UV-Vis spectrophotometric method.

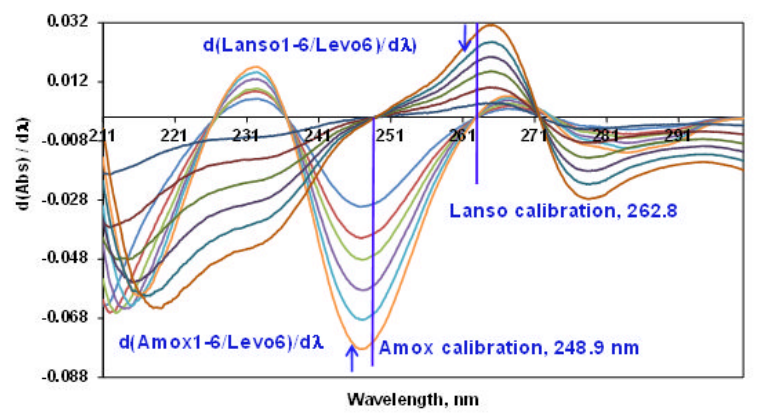

Figure 3. Ratio -first derivative - zero crossing UV-Vis absorption spectra of Amox1-6/Levo6 and Lanso1-6/Levo6 spectra ratios (Levo6: Levofloxacin $20 \mathrm{mg} / \mathrm{L}$ )

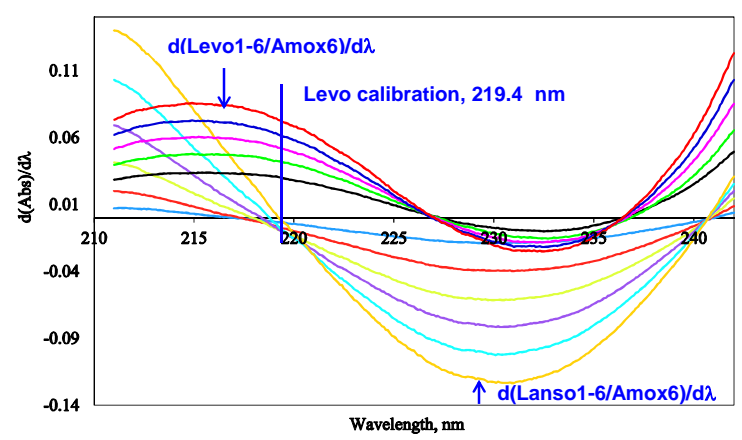

Figure 4. Ratio -first derivative - zero crossing UV-Vis absorption spectra of Levo1-6/Amox6 and Lanso1-6/Amox6 spectra ratios (Amox6: Amoxicillin 40 mg/L)

\section{Calibration curves}

The calibration curve of Amox was formed from the absorbance values at the wavelength of $248.9 \mathrm{~nm}$ in Fig. 3, in which the others have constant absorption values on these spectra. The obtained calibration curve for Amox is given in Fig. 5a. Similarly, the calibration curve of Lanso as the second analyte was formed from the absorbance values at the wavelength of 262.8 $\mathrm{nm}$ in Fig. 3. The calibration curve of Lanso is given in Fig. 5b. As the third analyte, the calibration curve of Levo was obtained from the absorption values at the wavelength of $219.4 \mathrm{~nm}$ in Fig. 4. The calibration curve of Levo is given in Fig. 5c. The calibration and regression data for Amox, Levo and Lanso were summarized in
Table 1. The limit of detection (LOD) and limit of quantitation (LOQ) of the method were obtained by standard deviation of response and slope method. The LODs and LOQs were calculated by using $\mathrm{LOD}=3.3 \times(\mathrm{SD} / \mathrm{S})$ and $\mathrm{LOQ}=10 \times(\mathrm{SD} / \mathrm{S})$ equations, where 'SD' represents the standard deviation of the response and ' $S$ ' is the slope of the calibration curves. From the calibration calculations of Amox, Levo and Lanso in their ternary mixtures, good linearity with high regression coefficients $\left(\mathrm{R}^{2}: 0.9987,0.9993\right.$ and 0.9996), and low LOD (1.03, 0.37 and $0.29 \mathrm{mg} / \mathrm{L})$ and low LOQ (3.42, 1.22 and $0.95 \mathrm{mg} / \mathrm{L})$ values were obtained for their working concentration ranges. Table 2 shows the results of the accuracy as recovery\% and the precision as RSD obtained from the calibration measurements.
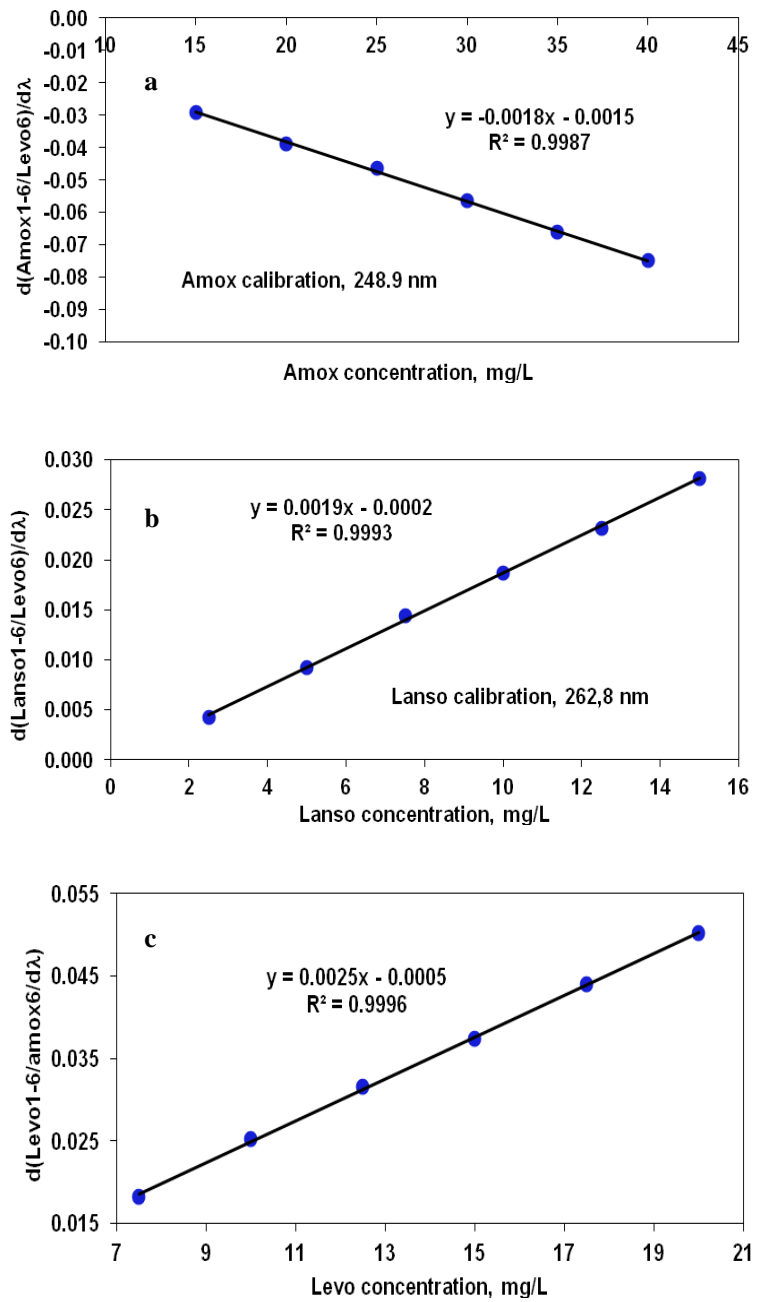

Figure 5. Calibration curves of a) Amox, b) Lanso and c) Levo 
Table 1. Calibration and regression data.

\begin{tabular}{lclcccc}
\hline Analyte & $\boldsymbol{\lambda}(\mathbf{n m})$ & Calibration equation & $\boldsymbol{R}^{2}$ & Range $(\mathbf{m g} / \mathbf{L})$ & $\mathbf{L O D}(\mathbf{m g} / \mathbf{L})$ & $\mathbf{L O Q}(\mathbf{m g} / \mathbf{L})$ \\
\hline Amox & 248.9 & $\mathrm{~A}=-0.0018 \mathrm{C}_{\text {Amox }}-0.0015$ & 0.9987 & $3.42-40$ & 1.03 & 3.42 \\
Lanso & 262.8 & $\mathrm{~A}=0.0019 \mathrm{C}_{\text {Lanso }}-0.0002$ & 0.9993 & $1.22-15$ & 0.37 & 1.22 \\
Levo & 219.4 & $\mathrm{~A}=0.0025 \mathrm{C}_{\text {Levo }}-0.0005$ & 0.9996 & $0.95-20$ & 0.29 & 0.95 \\
\hline
\end{tabular}

Table 2. Calibration measurements.

\begin{tabular}{|c|c|c|c|c|c|c|c|c|c|}
\hline \multirow{2}{*}{ No } & \multicolumn{3}{|c|}{ Added (mg/L) } & \multicolumn{3}{|c|}{ Found $(\mathrm{mg} / \mathrm{L})$} & \multicolumn{3}{|c|}{ Recovery (\%) } \\
\hline & Amox & Lanso & Levo & Amox & Lanso & Levo & Amox & Lanso & Levo \\
\hline C1 & 15 & 2.5 & 7.5 & 15.78 & 2.45 & 7.78 & 105.2 & 98.0 & 103.7 \\
\hline C2 & 20 & 5.0 & 10.0 & 19.95 & 5.09 & 9.91 & 99.8 & 101.8 & 99.1 \\
\hline C3 & 25 & 7.5 & 12.5 & 24.27 & 7.48 & 12.08 & 97.1 & 99.7 & 96.6 \\
\hline C4 & 30 & 10.0 & 15.0 & 29.46 & 10.04 & 15.06 & 98.2 & 100.4 & 100.4 \\
\hline C5 & 35 & 12.5 & 17.5 & 34.57 & 12.37 & 17.63 & 98.8 & 99.0 & 100.7 \\
\hline \multirow[t]{4}{*}{ C6 } & 40 & 15.0 & 20.0 & 40.97 & 15.07 & 20.05 & 102.4 & 100.5 & 100.3 \\
\hline & & & & & & Mean & 100.25 & 99.90 & 100.13 \\
\hline & & & & & & SD & 3.02 & 1.32 & 2.31 \\
\hline & & & & & & RSD $\%$ & 3.01 & 1.32 & 2.31 \\
\hline
\end{tabular}

(C: Calibration solution)

\section{Validation of method}

The applicability of the developed ratio first order derivative - zero crossing method for the ternary mixture of Amox, Levo and Lanso was tested in several synthetic mixtures of their different proportions. The prepared synthetic 18 mixture samples were measured on the UV-Vis spectrophotometer and the concentrations of the drug analytes were calculated by using the proposed method. The accuracy and precision of the method were found for each analytes. The results are given in Table 3 . The accuracies were found as the recoveries of $100.0 \%, 99.2 \%$ and $102.5 \%$, and the precisions were as the RSD\% values of 1.37, 2.04 and 2.64 for Amox, Levo and Lanso, respectively. In our previous work [4], the ternary mixture analysis of Amox, Lanso and Levo have been studied by using HPLC method. In this study, the mixture of the same combination was studied by ratio - first derivative - zero crossing UV-Vis absorption spectrophotometric method. In the validation measurements by using the HPLC method, the recoveries were $104.1 \%, 98.3 \%$, and $101.2 \%$ and the RSD\% values were $3.91 \%, 2.55 \%$ and $2.18 \%$ for Amox, Lanso and Levo, respectively. These comparisons show that this UV-Vis absorption method has relatively better accuracy and precision values than the HPLC method. As a result, the ratio- first order derivative - zero crossing method can be applied to the ternary mixtures of Amox, Levo and Lanso with good accuracies and high precisions.

\section{Analysis of pharmaceutical tablets}

The proposed ratio - first order derivative - zero crossing spectrophotometric method was applied to the analyses of Amox, Levo and Lanso in pharmaceutical tablets. Six samples solutions were prepared by dissolving Largopen, Lansor and Tavanic commercial drug tablets for Amox (25 $\mathrm{mg} / \mathrm{L})$, Lanso $(7.5 \mathrm{mg} / \mathrm{L})$ and Levo $(12.5 \mathrm{mg} / \mathrm{L})$. After the dissolution of them, the final dilutions were done by using $\mathrm{MeOH}: \mathrm{H}_{2} \mathrm{O}$ (50:50v/v) mixture solvent as similar to the calibration solutions. The obtained analysis results of the tablets are given in Table 4. Good accuracy and precision values were found in the analyses of the pharmaceutical tablets. The ratio - first order derivative - zero crossing spectrometric method is also suitable to prevent the interferences of the matrices in drug tablets. The method is precise, accurate and simple. Also, no separation step is required [37, 38]. As a result, the ratio - first order derivative - zero crossing spectrometric method can be used in the analyses of the ternary mixtures of Amox, Levo and Lanso. 
Table 3. Validation measurements.

\begin{tabular}{|c|c|c|c|c|c|c|c|c|c|}
\hline \multirow{2}{*}{ No } & \multicolumn{3}{|c|}{ Added (mg/L) } & \multicolumn{3}{|c|}{ Found (mg/L) } & \multicolumn{3}{|c|}{ Recovery (\%) } \\
\hline & Amox & Lanso & Levo & Amox & Lanso & Levo & Amox & Lanso & Levo \\
\hline V1 & 40 & 7.5 & 12.5 & 40.38 & 7.71 & 13.02 & 101.0 & 102.8 & 104.1 \\
\hline V2 & 35 & 7.5 & 12.5 & 35.36 & 7.48 & 12.65 & 101.0 & 99.7 & 101.2 \\
\hline V3 & 30 & 7.5 & 12.5 & 30.97 & 7.80 & 13.00 & 103.2 & 104.0 & 104.0 \\
\hline V4 & 25 & 7.5 & 12.5 & 25.10 & 7.49 & 13.08 & 100.4 & 99.9 & 104.6 \\
\hline V5 & 20 & 7.5 & 12.5 & 20.25 & 7.68 & 13.13 & 101.3 & 102.4 & 105.0 \\
\hline V6 & 15 & 7.5 & 12.5 & 15.14 & 7.51 & 12.65 & 101.0 & 100.1 & 101.2 \\
\hline V7 & 25 & 7.5 & 20.0 & 24.88 & 7.51 & 20.49 & 99.5 & 100.1 & 102.4 \\
\hline V8 & 25 & 7.5 & 17.5 & 25.02 & 7.52 & 18.33 & 100.1 & 100.3 & 104.8 \\
\hline V9 & 25 & 7.5 & 15.0 & 25.45 & 7.39 & 15.18 & 101.8 & 98.5 & 101.2 \\
\hline V10 & 25 & 7.5 & 12.5 & 25.01 & 7.33 & 12.96 & 100.0 & 97.7 & 103.7 \\
\hline V11 & 25 & 7.5 & 10.0 & 24.66 & 7.37 & 10.36 & 98.6 & 98.3 & 103.6 \\
\hline V12 & 25 & 7.5 & 7.5 & 24.56 & 7.30 & 7.65 & 98.2 & 97.3 & 102.0 \\
\hline V13 & 25 & 15 & 12.5 & 24.71 & 15.17 & 12.99 & 98.8 & 101.1 & 104.0 \\
\hline V14 & 25 & 12.5 & 12.5 & 24.94 & 11.87 & 12.18 & 99.8 & 95.0 & 97.4 \\
\hline V15 & 25 & 10.0 & 12.5 & 24.68 & 9.67 & 12.96 & 98.7 & 96.7 & 103.7 \\
\hline V16 & 25 & 7.5 & 12.5 & 24.67 & 7.54 & 12.55 & 98.7 & 100.5 & 100.4 \\
\hline V17 & 25 & 5.0 & 12.5 & 24.65 & 4.72 & 12.62 & 98.6 & 94.4 & 100.9 \\
\hline \multirow[t]{4}{*}{$\mathrm{V} 18$} & 25 & 2.5 & 12.5 & 24.67 & 2.41 & 12.50 & 98.7 & 96.2 & 100.0 \\
\hline & & & & & & Mean values & 100.0 & 99.2 & 102.5 \\
\hline & & & & & & SD & 1.37 & 2.64 & 2.04 \\
\hline & & & & & & RSD \% & 1.37 & 2.67 & 1.99 \\
\hline
\end{tabular}

(V: Validation solution)

Table 4. Analyses of commercial pharmaceuticals.

\begin{tabular}{|c|c|c|c|c|c|c|c|c|c|}
\hline \multirow[b]{2}{*}{ No } & \multicolumn{3}{|c|}{ Added (mg/L) } & \multicolumn{3}{|c|}{ Found (mg/L) } & \multicolumn{3}{|c|}{ Recovery } \\
\hline & Amox & Lanso & Levo & Amox & Lanso & Levo & $\operatorname{Amox}$ & Lanso & Levo \\
\hline $\mathrm{T} 1$ & 25 & 7.5 & 12.5 & 24.72 & 7.36 & 12.72 & 988.8 & 29.4 & 508.9 \\
\hline $\mathrm{T} 2$ & 25 & 7.5 & 12.5 & 24.63 & 7.90 & 13.05 & 985.0 & 31.6 & 521.9 \\
\hline $\mathrm{T} 3$ & 25 & 7.5 & 12.5 & 24.84 & 7.09 & 12.91 & 993.5 & 28.4 & 516.4 \\
\hline $\mathrm{T} 4$ & 25 & 7.5 & 12.5 & 24.69 & 7.48 & 13.02 & 987.6 & 29.9 & 520.7 \\
\hline $\mathrm{T} 5$ & 25 & 7.5 & 12.5 & 24.65 & 7.03 & 12.53 & 986.0 & 28.1 & 501.1 \\
\hline \multirow[t]{10}{*}{ T6 } & 25 & 7.5 & 12.5 & 24.68 & 7.36 & 13.04 & 987.4 & 29.4 & 521.7 \\
\hline & & & & & & Mean & 988.0 & 29.5 & 515.1 \\
\hline & & & & & & SD & 2.97 & 1.24 & 8.45 \\
\hline & & & & & & $\mathrm{RSD} \%$ & 0.30 & 4.22 & 1.64 \\
\hline & & & & & & SE & 0.94 & 0.39 & 2.67 \\
\hline & & & & & & CL (0.05) & 1.84 & 0.77 & 5.24 \\
\hline & & & & & & $t$ test & 0.0087 & 0.8117 & 0.6545 \\
\hline & & & & & & $t$ critical & 2.5706 & 2.5706 & 2.5706 \\
\hline & & & & & & $F$ test & 0.0063 & 1.1184 & 0.3792 \\
\hline & & & & & & $F$ critical & 0.1980 & 5.0503 & 0.1980 \\
\hline
\end{tabular}

(T: Tablet solution, $\mathrm{n}=3$ ) (Amox: $1000 \mathrm{mg} / \mathrm{tablet}$ Lanso: $30 \mathrm{mg} /$ tablet, levo: $500 \mathrm{mg} / \mathrm{tablet}$; $t$ and $F$ tests were calculated based on previous HPLC method values [4]). 


\section{Comparing with the studies in the literature}

It has not been reached to a study about the combination of Amox, Levo and Lanso about simultaneous determination by using any UV-Vis absorption spectrophotometric method. However, in the literature, there are studies about simultaneous determinations of Amox, Levo or Lanso with other drug reagents with UV-Vis absorption spectrophotometry. Some examples of the studies published in the literature about simultaneous determination in binary of ternary mixtures of Amox, Levo and Lanso with UV-Vis absorption spectroscopic methods are given in Table 5. First order and second order derivative, ratio - first order derivative - zero crossing UV-Vis absorption spectroscopic methods have been used in binary or ternary mixtures. The ternary mixtures are within limited numbers, although the binary mixtures have been studied extensively in the literature.

Table 5. Some simultaneous analyses of binary or ternary mixtures including Amox, Lanso and Levo with UV-Vis spectrophotometric methods.

\begin{tabular}{|c|c|c|c|}
\hline Mixture & Method & Conditions & Reference \\
\hline $\begin{array}{l}\text { Binary: Amoxicillin (Amox) } \\
\text { and Phenylephrine } \\
\text { hydrochloride (Phe). }\end{array}$ & $\begin{array}{l}\text { First and second order derivation of } \\
\text { ratio spectra UV-Vis } \\
\text { spectrophotometric methods }\end{array}$ & $\begin{array}{l}\text { Wavelengths: } 228,258,238,277 \mathrm{~nm} \text { (Phe); 226, } \\
241 \mathrm{~nm} \text { (Amox). Conc. ranges: 2-150 mg/L (Phe); 2- } \\
240 \mathrm{mg} / \mathrm{L} \text { (Amox). Solvent: Water }\end{array}$ & [39] \\
\hline $\begin{array}{l}\text { Binary: Amoxicillin (Amox) } \\
\text { and Clavulanate (Cla) }\end{array}$ & $\begin{array}{l}\text { Ratio- first order derivative UV -Vis } \\
\text { spectrophotometric methods }\end{array}$ & $\begin{array}{l}\text { Wavelengths: } 283.3 \mathrm{~nm}(\text { Amox }) ; 287.9 \mathrm{~nm}(\mathrm{Cla}) \text {. } \\
\text { Conc. ranges : } 100.0-160.0 \mu \mathrm{g} / \mathrm{mL} \text { (Amox); } 10.0 \\
-35.0 \mu \mathrm{g} / \mathrm{mL} \text { (Cla). Solvent: Water }\end{array}$ & {$[40]$} \\
\hline $\begin{array}{l}\text { Ternary: Omeprazole } \\
\text { (Ome), Lansoprazole } \\
\text { (Lanso) and Pantoprazole } \\
\text { (Pan) }\end{array}$ & $\begin{array}{l}\text { Second derivative (I), Orthogonal } \\
\text { functions (II), and difference }(\Delta \mathrm{A}) \\
\text { (III) } \mathrm{UV}-\mathrm{Vis} \text { spectrophotometric } \\
\text { methods }\end{array}$ & $\begin{array}{l}\text { Wavelengths: } 306.2 \mathrm{~nm} \text { (Ome); } 292.4 \mathrm{~nm} \text { (Lanso); } \\
295.4 \mathrm{~nm} \text { (Pan) (I); } 306 \mathrm{~nm}(\text { Ome), } 293 \mathrm{~nm} \\
\text { (Lanso); nm } 295 \mathrm{~nm} \text { (Pan) (II); 256, } 280 \mathrm{~nm} \\
\text { (Ome), 254, } 250 \mathrm{~nm} \text { (Lanso), 254, 256, } 250 \mathrm{~nm} \\
\text { (Pan) (III). Conc. ranges: 0.5-3.5 } \mu \mathrm{g} / \mathrm{mL} \\
\text { Solvent: 0.1 M sodium hydroxide }\end{array}$ & [41] \\
\hline $\begin{array}{l}\text { Lansoprazole (Lanso), and } \\
\text { Aspirin (Asp) }\end{array}$ & $\begin{array}{l}\text { First order derivative UV-Vis } \\
\text { spectrophotometric method }\end{array}$ & $\begin{array}{l}\text { Wavelengths: } 232 \mathrm{~nm} \text { (Lanso), } 222 \mathrm{~nm} \text { (Asp). } \\
\text { Conc. ranges: } 4-20 \mu \mathrm{g} / \mathrm{mL} \text { Solvent: Methanol }\end{array}$ & {$[42]$} \\
\hline $\begin{array}{l}\text { Binary: Levofloxacin } \\
\text { hemihydrate (Levo) and } \\
\text { ambroxol hydrochloride } \\
\text { (Abh) }\end{array}$ & $\begin{array}{l}\text { First order derivative - zero } \\
\text { crossing UV -Vis spectrophotometric } \\
\text { method }\end{array}$ & $\begin{array}{l}\text { Wavelengths: } 255.7 \mathrm{~nm} \text { (Abh); } 353 \mathrm{~nm} \text { (Levo). } \\
\text { Conc. ranges: } 5-40 \mu \mathrm{g} / \mathrm{mL} \text { (Levo); } 3-10.5 \mu \mathrm{g} / \mathrm{mL} \\
\text { (Abh). Solvent: } 0.1 \mathrm{~N} \text { urea }\end{array}$ & [43] \\
\hline $\begin{array}{l}\text { Binary: Azithromycin (Azi), } \\
\text { and Levofloxacin (Levo) }\end{array}$ & $\begin{array}{l}\text { Multicomponent mode analysis (I), } \\
\text { absorbance ratio (II), and partial least } \\
\text { square calibration (III) methods }\end{array}$ & $\begin{array}{l}\text { Wavelengths: } 245.0 \mathrm{~nm} \text { (Azi), } 290.0 \mathrm{~nm} \text { (Levo) } \\
\text { (I); } 245.0 \mathrm{~nm} \text { (Azi) } 209.60 \mathrm{~nm}(\mathrm{Levo}) \text { (II); 200-350 } \\
\mathrm{nm} \text { (II). Conc. ranges: } 20-100 \mu \mathrm{g} / \mathrm{mL} \text { (I and II); } 2- \\
10 \mu \mathrm{g} / \mathrm{mL} \text { (III). Solvent: } 0.1 \mathrm{~N} \mathrm{HCl}\end{array}$ & [44] \\
\hline $\begin{array}{l}\text { Ternary: } \\
\text { Amoxicillin (Amox), } \\
\text { Lansoprazole (Lanso), } \\
\text { Levofloxacin (Levo) }\end{array}$ & $\begin{array}{l}\text { Ratio - first order derivative - zero } \\
\text { crossing UV-Vis spectrophotometric } \\
\text { method }\end{array}$ & $\begin{array}{l}\text { Wavelengths: } 248.9 \mathrm{~nm} \text { (Amox); } 262.8 \mathrm{~nm} \\
\text { (Lanso); } 219.4 \mathrm{~nm} \text { (Levo). Conc. ranges: } 3.42-40 \\
\text { mg/L (Amox); } 1.22 \text { - } 15.0 \mathrm{mg} / \mathrm{L} \text { (Lanso); } 0.95-20.0 \\
\text { mg/L (Levo). Solvent: } \mathrm{MeOH}: \mathrm{H}_{2} \mathrm{O}(50: 50 \mathrm{v} / \mathrm{v})\end{array}$ & This study \\
\hline
\end{tabular}




\section{Conclusion}

In the present work, a ratio - first order derivative - zero crossing UV-Vis Spectrophotometric method has been developed and validated for the determination of amoxicillin, lansoprazole and levofloxacin in pharmaceuticals. The results showed that amoxicillin, lansoprazole and levofloxacin could be determined successfully and simultaneously. The proposed method does not require any prior separation step. The ratio - first order derivative - zero crossing UV-Vis spectrophotometric method can be used for the ternary mixtures of amoxicillin, lansoprazole and levofloxacin with good accuracy and precision in the synthetic mixtures or in the pharmaceutical dosage forms of them.

\section{References}

1. M. Dousa and R. Hosmanová, $J$. Pharmaceut. Biomed., 37 (2005) 373. doi: 10.1016/j.jpba.2004.10.010.

2. D. Hoang $\mathrm{Vu}$ and T. Giang Do, J. Young Pharm., 2 (2010) 190.

doi: 10.4103/0975-1483.63168.

3. D. S. Nikam, C. G. Bonde, S. J. Surana, G. Venkateshwarlu and P. G. Dekate, Int. J. Pharm. Tech. Res., 1 (2009) 935. http://www.sphinxsai.com/PTVOL3/PT=86, $\% 20$

CHANDRAKNAT\%20BONDE, \%20(935939).pdf.

4. M. Gülfen, Y. Canbaz and A. Özdemir, $J$. Anal. Test., 4 (2020) 45. doi:10.1007/s41664-020-00121-4.

5. R. Davis and H. M. Bryson, Drugs, 47 (1994) 677. doi: $10.2165 / 00003495$.

6. S. Naveed, N. Sultana, M. S. Arayne and H. Dilshad, J. Sci. Innov. Res., 3 (2014) 91. http://www.jsirjournal.com/Vol3_Issue1_01 $\underline{5 . p d f}$.

7. I. F. Al-Momani, Anal. Lett., 39 (2006) 741. doi: 10.1080/00032710600611186.

8. K. Borner, E. Borner and H. Lode, Chromatographia, 45 (1997) 450. doi: 10.1007/BF02505600.

9. I. Tadwee, P. Ade, P. Bhalerao, A. Khan and S. Shahi, World J. Pharmac. Res., 6 (2017) 915. doi : 10.20959/wipr201717-10405.

10. J. B. Dave and S.K. Banerjee, Indian J. Pharm. Sci., 48 (1986) 73.

https://www.ijpsonline.com/abstract/spectro photometric-estimation-of-amoxycillin-byreaction-with-diazotized-primary-aromaticamines-2109.html.

11. K. Basavaiah, V. Ramakrishna and B. C. Somashekar, Eclet Quím., 32(2007) 57. doi: 10.1590/S0100-46702007000100008.

12. N. Özaltın, J. Pharm. Biomed. Anal., 20 (1999) 599. doi: 10.1016/S0731-7085(99)00061-8.

13. A. M. El-Brashy, M. E. Metwally and F. A. El-Scpai, Farmaco, 59 (2004) 809. doi: 10.1016/j.farmac.2004.07.001.

14. C. S. P. Sastry, K. R. Rao and D. S. Prasad, Talanta, 42 (1995) 311. doi: 10.1016/0039-9140(95)01380-T.

15. Z. Feng, X. Bian, Z. Zhi and T. Shen, $J$. Pharm. Biom. Anal., 21 (1999) 355. doi: 10.1016/S0731-7085(99)00121-1.

16. G. Oriquat, A. Osman, M. Abdul-Azim and S. Abuhamdah, J. Appl. Pharm. Sci., 4 (2014) 57. doi: 10.7324/JAPS.2014.40410.

17. J. A. O. Gonzalez, M. C. Mochon and F. T. B. Rosq, Talanta, 52 (2000) 1149. doi: 10.1016/S0039-9140(00)00484-7.

18. A. H. Aktaş and A. M. Sarıdağ, $J$. Chromatogr. Sci., 55 (2017) 798. doi: 10.1093/chromsci/bmx039.

19. M. L. Storms and J. T. Stewart, J. Liq. Chromatogr. R. T., 25 (2002) 2433.

doi: 10.1081/JLC-120014265.

20. K. Basavaiah, V. Ramakrishna, U. R. Anilkumar and K. Udaya, Indian. J. Chem. Technol., 13 (2006) 549. http://hdl.handle.net/123456789/7098.

21. S. Djabarouti, E. Boselli, B. Allauuchiche, B. Ba, A. T. Nguyen, J. B. Gordien, J. M. Bernadou, M. C. Saux and D. Breilh, J. Chromatogr. B, 799 (2004) 165. doi: $10.1016 /$ j.jchromb.2003.10.031.

22. A. Czyrski and E. Szałek, J. Anal. Chem., 71 (2016) 840. doi: $10.1134 / \mathrm{S} 1061934816080049$.

23. S. A. Nabi, M. A. Khan and S. N. Khowaja, Acta Chromatogr., 16 (2006) 164. https://www.infona.pl/resource/bwmeta1.ele ment.baztech-article-BAT3-0037-0017. 
24. N. Rahman and S. Khan, Ind. Eng. Chem. Res., 57 (2018) 9351.

doi: $10.1021 /$ acs.iecr.8b01281.

25. A. Tivesten, S. Folestad, V. Schonbacher and K. Svensson, Chromatographia, 49 (1999) S7. doi: 10.1007/BF02468970.

26. C. Yardımcı and C. Özaltın, Analyst, 126 (2001) 361. doi: 10.1039/b008800p.

27. A. Radi, J. Pharm. Biomed. Anal., 31 (2003) 1007. doi: 10.1016/S0731-7085(02)00707-0.

28. J. Y. Huang, T. Bao, T. X. Hu, W. Wen, X.H. Zhang and S. F. Wang, Microchim. Acta, 18 (2017) 127. doi: 10.1007/s00604-016-1982-5.

29. G. Altiokka, Z. Atkosar and N. O. Can, $J$. Pharm. Biom. Anal., 30(2002) 881. doi: 10.1016/S0731-7085(02)00354-0.

30. H. Wang, Y. Sun ,X. Meng, B. Yang, J. Wang Y. Yang and J. Gu, J. Sep. Sci., 17 (2015) 2960. doi: $10.1002 /$ jssc. 201500462 .

31. J. Karpińska, A. Sokół and M. Rożko, Anal. Lett., 42 (2009) 1203. https://doi.org/10.1080/00032710902890488.

32. A. H. Kamal, S. F. El-Malla and S. F. Hammad, Eur. J. Pharm. Med. Res., 3 (2016) 348.

https://storage.googleapis.com/journaluploads/ejpmr/article issue/1454480552.pdf.

33. F. E. Suliman and S. M. Sultan, Talanta, 43 (1996) 559. doi: 10.1016/0039-9140(95)01771-2.

34. F. Salinas, J. B. Nevado and A. E. Mansilla, Talanta, 37 (1990) 347. doi: 10.1016/0039-9140(90)80065-n.

35. J. B. Nevado, C. G. Cabanillas and F. Salinas, Talanta, 39 (1992) 547. https://doi.org/10.1016/00399140(92)80179-H.
36. M. H. Abdel-Hay, A. A. Gazy E. M. Hassan and T. S. Belal, J. Chin. Chem. Soc-Taip., 55 (2008) 971.

https://doi.org/10.1002/jccs.200800144.

37. B. Uslu and S. A. Özkan, Anal. Lett., 35 (2002) 303.

https://doi.org/10.1081/AL-120002531.

38. N. Erk, Pharmazie, 58 (2003) 796. https://www.ingentaconnect.com/content/go vi/

pharmaz/2003/00000058/00000011/art0000

5 ?crawler $=$ true \&mimetype $=$ application/pdf.

39. A. M. Aljeboree and A. N. Alshirifi, Int. J. Pharm. Qual. Assur., 10 (2019) 168.

https://ijpqa.com/index.php/IJPQA/article/vi ew/740/279.

40. V. T. Huong and V. D. Hoang, Int. J. Pharm. Tech Res., 1 (2009) 1173.

http://sphinxsai.com/PTVOL4/pdf vol4/PT =34(1173-1181).pdf.

41. A. A. M. Wahbi, O. Abdel-Razak, A. A. Gazy, H. Mahgoub and M. S. Moneeb, $J$. Pharmaceut. Biomed., 30 (2002) 1133. https://doi.org/10.1016/S07317085(02)00464-8.

42. G. Kumaraswamy, R. Lalitha and D. S. Kumar, Asian J. Res. Pharm. Sci., 6 (2016) 185. doi: 10.5958/2231-5659.2016.00025.4.

43. C. Mathew, B. Suman, M. Ajitha and P. R. S. Babu, Orient. J. Chem., 30 (2014) 1385. http://dx.doi.org/10.13005/ojc/300359.

44. L. Sivasubramanian, D. Balanagamani and R. Mamatha, J. Pharm. Res., 12 (2018) 679. http://jprsolutions.info/files/final-file5af198541b12a9.19298672.pdf. 